\title{
Casting Curricular Circles, or The Sorcerer, the Phantom and the Troubadour
}

\author{
LAURA JEWETT \\ University of Texas Brownsville (USA)
}

\begin{abstract}
A professor is a sorcerer, and his job is to make a phantom appear. To that end, he makes noise, bangs drums, gesticulates, sings and dances. Suddenly, if he is successful, a door opens, and Philosophy appears - then the students need not listen to the professor anymore. Michel Serres quoted in Haven, 2009, p. 2
\end{abstract}

Even a top-shelf shaman needs a spell. As any curandera knows, invoking a spirit or opening a door to the unknowable requires ritual order - celestial scope and sequencestruck against the anomie of deep disorder. The magic resides in the sympathetic interaction between the incantation and its performance, and in the tense transaction among form and content. Scientists and teachers know this too. What follows is a vignette describing a particular sequence of curricular rituals involving people who are scientists and teachers both, trying to bring forth knowledge that is at once old and new.

\section{Casting Circles}

Before the spell comes the circle. Before the banging, gesticulating, dancing and singing that Serres (2009) describes, boundaries between physical and ethereal worlds must be drawn. These boundaries might be more generatively seen as hermeneutic rather than hermetic barriers, however (Grassie, 2011). In hermeneutic as well as shamanic circles, the borders between what is and what is becoming, and between notions of the particular and the whole are often configured in terms of interpenetrating circles, or spheres of temporary coherence. Heidegger cast a hermeneutic circle to describe his understanding 
of the relationship between parts and wholes: that our understanding of any phenomenological whole is contingent upon degrees of partial pre-understanding, and that this partial knowledge is contingent upon our grasp of the whole. For Heidegger, this circle was cast as an interpretive arena.

Similarly, this vignette takes place within an interpretive and symbolic arena, one that I call "curriculum." More particularly, it takes place within the epistemological confines of a Master's level course titled Curriculum and the Secondary School. The course was designed primarily for a cadre of twenty-one secondary science teachers who are part of a statewide grant collaborative designed to "provide sustained and high intensity professional development to P-12 teachers of science and mathematics across the state" (UT-Brownsville Collaborative for Excellence in Mathematics and Science Teaching, 2010). All but four of the twenty-one students in the course were part of this competitive program, which pays for their tuition and books and provides other financial assistance. Ever loyal to the scientific method, these students, who are also science teachers, are carefully cultivated purveyors of the empirical, prepared to defend the truth of their discipline with evidence and logic. Yet through our joint action conjuring up new understandings, I also found these teachers divining visions of a wonderful science curriculum, one "designed to excite wonder, awe and appreciation of the world and the place of human beings in it" (Whitehead as quoted in Noddings, 2006, p. 290).

Toward these ends, I proceeded by aligning the rather general aims of this secondary curriculum studies course with the constellation of particular interests common to this group. Our reciprocal aim was to explore scientific approaches to curriculum and curricular approaches to issues of secondary science. We began with a mantra of sorts: "Good questions outrank easy answers" (attributed to Paul Samuelson). We asked ourselves and our colleagues, as well as people in other circles, open questions such as "what is curriculum?" and "what is science?" In an effort to, as Serres (2009) suggests, "open the door," so that the philosophical underpinnings of curriculum might appear to us alongside the philosophy of science, we banged the drums of Aristotle, Socrates, Descartes and Darwin in syncopation with Bobbitt (1918); Dewey (1929); Tyler (1949); Bateson (1972); Bruner (1986); Doll (1993) Prigogine (1997); Morrison (2008); and Claxon (2010).

We then cast a conversational circle, through which we attempted to conjure new understanding through a process of recursive/discursive inquiry, the "story circle." I adapted the form of the story circle from New Orleans civil rights activist John O'Neil, and its theory from the work of Buber (1958); Gadamer (1976); Bakhtin (1986); Panikkar (1988); and Doll (1993). In order to create a ritualized space, I required that we all move our chairs into a circle and sit together without the usual desks, backpacks, purses, phones, or computers that shield us from one another. For those of us accustomed to the electronic tether or the old-school comforts of taking notes, sitting in a circle without accoutrements - but with the sole charge of being fully present or at least generatively absent-often feels oddly open and vulnerable, especially at first. Such disequilibrium is characteristic of rites of passage, both curricular and cultural. This ritual cycle began with a student asking a hermeneutic question based on course readings, some of which 
are common and some of which are not. The student "hermeneut" then assigned the amount of time each participant would get to respond to the question. The conversation then proceeded clockwise, each conversant contributing their response to their interpretation of the question, uninterrupted, within the established time constraint.

The theoretical insight this cycle was designed to generate relies on the play of multiple perspectives embodied as tacit understandings, from which new questions reflecting more nuanced understanding emerge, which in turn are articulated as new tacit understanding as the ritual cycle begins again. As Donald Schon (1983) quoted in Doll (1993) notes, it is through acts of public inquiry such as conversation and dialogue that we can begin to "reflect on [our] own tacit understandings, thereby starting the dual process of (1) bringing these understandings to consciousness and (2) changing them at the same time" (p. 62). This process is "recursive and relational; questions lead to other questions, and so on; all knowledge falls back upon itself" (Jewett, 2005, p. 294). Interpretations are solicited but not required from each hermeneut. When each had had a chance to contribute, the person who asked the initial question decided whether to repeat the cycle, or open up the conversation to new configurations of interpretation.

Casting this sort of curricular circle can be powerful. The ritualized process of recursive/discursive inquiry forms a feedback loop that can foster conditions conducive to self-reflexivity. The constraints inherent to the conversational structure provide "sources of coherence that allow a collective to maintain a focus of purpose/identity" (Davis \& Sumara, 2006, p. 147). Our hermeneutic circle was tight and the richness of the layered interpretation the story circle gave rise to was especially pronounced in the case of the secondary science teachers. Our deepening sense of scientific purpose and disciplinary identity, the rhythmic reverberations of our ritual reflection, and our theoretical gesticulations certainly were spellbinding. But our overall incantation-the interpretive patterns we were generating through reflexive conversation-didn't yet open a "diatopical" threshold of difference (Panikkar, 1989). Our assumptions and beliefs about science and secondary curriculum within our circle were not in radical contact with such assumptions outside our hermeneutic circle. According to Richard Dawkins (1997) "there's all the difference in the world between a belief that one is prepared to defend by quoting evidence and logic, and a belief that is supported by nothing more than tradition, authority or revelation" (Dawkins, 1997). Perhaps we were not casting an interpretive circle at all, and instead were being cast by an established dichotomy of the sort Dawkins (1997) evokes - the kind of dichotomy that spooks the sorts of curricular phantoms to which Serres (2009) alludes, and which we were trying to invoke.

\section{Invoking the Troubadour}

Speaking to the matter of secondary curriculum, Nell Noddings (2006) writes that "the basic structure of the secondary curriculum-organization around the traditional disciplines-probably will not change in the foreseeable future. However, every discipline can be stretched from the inside to provide richer, more meaningful studies" 
(p. 290). Changing the shape of matter from the inside out is, likewise, a sorcerer's trick. What would such alchemy mean for the matter at hand? If the scientific method is seen as the primary way scientists and science teachers evoke and commune with established epistemological authority of science, what might stretching this discourse from the inside out (in the service of enriching interpretation, not expanding authority) invoke?

In his Daxia lecture No. 87, titled The Wisdom of John Dewey and delivered at East China Normal University, William E. Doll Jr. (2010) uses John Dewey's (1970 [1919]) notion of wisdom to reveal a vision of science tempered with the humanities and adequately stretched to encompass a "tolerant wisdom of the other" (Serres, 1997 [1991], p. 122). Doll (2010) invokes Michel Serre's (1997 [1991]) archetypal "troubadour of knowledge" to embody a moral vision of science, "one based on wisdom: a wisdom which 'will weave the warp of the rediscovered humanities to the woof of expert exactitude'" (Serres, 1997, p. 184, in Doll, 2010).Via Doll's (2010) lecture, my secondary science curriculum students and I sought to invoke Serre's (1997 [1991] troubadour as a sort of familiar, or totem, representing the phantom other to which Serres (2009) alludes and which, to this point, had eluded our hermeneutic circle. According to Serres (1997 [1991]) the troubadour of knowledge, represents a synthesis of science and letters:

He is admittedly a rationalist, but he does not believe that all the requirements of reason are met by science. He tempers one with the other. Likewise, he never sees the social sciences as exhausting the content transmitted by the humanities-far from it. Thus for him there is as much rigor in a myth or a work of literature as in a theorem or an experiment and, inversely, as much myth in these as in literature (183).

Serre's (1997 [1991]) vision of a troubadour of knowledge offers us an archetypal, diatopical hermeneut capable of rationally hanging in multiple epistemological circles. Further, this archetype represens a healthy, collective, and individual "fear of the unitary solution" (Doll, 2010, p. 14). But we weren't so sure that $s /$ he was a scientistthat we hadn't fled science proper and in some volatile, mystical move conjured up a humanist instead. And while this was not so much a problem for the sorcerer whose disciplinary allegiances are more like whims, it presented deep dissonance for secondary science teachers guided by the rites dictated by the doctrine of scientific method.

As I suggested above, the circles we cast as struggling hermeneuts also cast us. It is clear that the epistemological constraints-or that which constitutes truth or knowledge outside the symbolic arena of the interpretive circles we inhabit- permeate the hermeneutic relations within these circles as well. As Panikkar (1988) suggests, we do not merely inhabit hermeneutic circles, "we create that circle through the existential encounter (p. 132). So it seemed that conjuring forth a troubadour/a of knowledge in any substantive way from our conversation, from our curriculum and ultimately from ourselves-required that we somehow transmute, albeit symbolically, our own existential reality of science-that "combustible mixture of ignorance and power" (Sagan, 1996, p. 26). And this was altogether an entirely different curricular matter, or perhaps more properly, a matter of curricular difference. 


\section{Corralling the Phantom}

Our curricular attempts to bring forth a troubadour/a of science by stretching scientific discourse from the inside out yielded what to us appeared to be a humanist hermeneutic, rather than a scientific one. Perhaps the degree to which Serre's (1997 [1991]) notion of the humanist hero worked against rather than from within the parameters of existential self-perception that structured the experience of these secondary science teachers was proportional to this troubadour's totemic potency. But invocation alone did not help us make manifest the elusive phantom that is rumored to hover around the complicated conversations that forge hermeneutic thresholds, where scientific and self-understanding meet the fecund interpretations of perceived hermeneutical otherness unencumbered by assumptions that these others share the same basic self-understanding we have. Before that, we tried to roust the phantom and force open the curricular door to the unknowable by casting expanding concentric structures of joint understanding through recursive/discursive transactions of self-reflexivity. This sequence of curricular rituals ends with a rite of reversal.

In this last act of curricular craft, instead of self-consciously working to expand the patterns of epistemological understanding among secondary science teachers studying curriculum, I applied generative constraints of curricular practice in order to reduce them. Rather than evoking Serre's archetypal troubadour to explain the links among bits and pieces - epistemological scraps - from complex systems, I put him to the ontological work of bringing these links more or less successfully into being (Law, 1997, p 8). As Fernandez (1991) reminds: "It is the performative element of divination, and not only its logical truth properties, that has the power to transform social realities (Fernandez 1991: 217). Our performance entailed using the troubadour of science, as interpreted through Doll (2010), to embody diverse curricular models. Students divided into groups and then "drew" from one of eight curricular models: Aims Model, Taba Inverted Model, Tyler's Ends-Means Model, The Olivia Model, Sayler Alexander Model, MacDonald's Model, The Zais Eclectic Model, The Parallel Curriculum Model (Henson, 2010). Then each group designed secondary science curriculum with the troubadour of knowledge as its aim while adhering to the parameters of their given model. The performance of striking an open-ended aim (our troubadour of science) against various constraints of existing, and for the most part rather static, curricular design models opened up our thinking about science, wisdom, and secondary curriculum in ways that our arguably more open, hermeneutical work did not. Paradoxically, we had to tether our troubadour in order to set her/his creative powers free. Parsons (2010) evokes a similar generative tension in his description of the creative process: "It's like a corral around your idea, a corral that you can move around in-but not too much. And its that limited movement that promotes creativity" (Parsons, 2010, p. 548). Likewise, our capacity for curricular magic in this last ritual sequence was not a product of self-reflexivity or innovation; rather, this creative force was itself a process contingent on transactions among the source of interpretation, the context of interpretation, the interpreter, and the object of interpretation. 


\section{Divining Difference}

Perhaps our alchemy was off kilter. Perhaps Serre's (2009) phantom need not be rousted by a noisy sorcerer, or conjured from the thin air of expansive social hope which is not yet. Nor must the vision of difference it reveals be communicated through the always already represented by a rowdy, archetypal anachronism of hermeneutic humanism, or the threat of meaty certainty. Perhaps, while we waited for the door to open, the phantom we sought - which all teaching and learning from time to time seeks - was/is wafting under the door and swirling up through cracks in the window sill; absolute diaphanous insinuation neither made nor found, a speck of a whisper of difference that reaches us gentle like a genuine hint, "as a response, which brings forth new worlds because it necessarily adds something (which was not present anywhere before it appeared) to what came before" (Osberg, Biesta, \& Cilliers, 2008, p. 226).

\section{References}

Bakhtin, M. (1981). The dialogic imagination: Four essays. Austin, TX: The University of Texas Press.

Bateson, G. (1972). Steps to an ecology of mind. Chicago: University of Chicago Press.

Bobbitt, F. Scientific method in curriculum making. (1918/2009). In D.J. Flinders \& S.J. Thorton (Eds.).The curriculum studies reader (pp. 52-61). New York: Routledge.

Bruner, J. (1986). Two Modes of Thought. In Actual minds, possible worlds (11-43). Cambridge, MA: Harvard University Press.

Buber, M. (1958). I and Thou. New York: Charles Scribner's Sons.

Claxon, G. (2010). The virtues of uncertainty: A character curriculum for the learning age. In D. Lorimer \& O. Robinson (Eds.). A New Renaissance: Transforming Science, Spirit and Society (272-281). Great Britain: Floris Books.

Davis, B. \& Sumara, D. (2006). Complexity and education: Inquiries into learning, teaching, and research. Mahwah, NJ: Lawrence Erlbaum.

Dawkins, Richard (1997). Is science a religion? American Humanist Association. Available http://www.thehumanist.org/humanist/articles/dawkins.html.

Dewey, J. (1929). My pedagogic creed. Journal of the National Education Association, 18 (9), 291-295.

Doll, W. E., Jr. (1993). A post-modern perspective on curriculum. New York: Teachers College Press.

Doll, W.E., Jr. (2010). The Wisdom Of John Dewey. Delivered November $9^{\text {th }}, 2010$. East China Normal University. Daxia Lecture \# 87.

Fernandez, J (1991). Afterword. In P.M. Peek (Ed.). African Divination Systems: Ways of Knowing, Bloomington: Indiana University Press.

Gadamer, H.G. (1976). Philosophical hermeneutics. Berkeley: University of California Press.

Grassie, W. (2011). A Review of Robert Ulanowicz's Third Window: Natural Life Beyond Newton and Darwin. The Global Spiral. Retrieved from http://www.metanexus.net/magazine/tabid/68/id/10998/Default.aspx

Haven, C. (2009, May 27). Michel Serres, one of France's 'immortels,' tells the 'grand récit' at Stanford. Stanford Report. Retrieved from http://news.stanford.edu/news/2009/may27/serres-052709

Henson, K.T. (2010). Curriculum planning: Integrating multiculturalism, constructivism and education reform. Longrove, IL: Waveland Press.

Jewett, L. (2005). Minding culture. In W.E. Doll, M.J. Fleener, D. Trueit, J. St. Julien (Eds.). Chaos, complexity, curriculum and culture: A conversation, (pp. 277-297). New York: Peter Lang.

Law, J. (1997). Traduction/trahisonø. Sociology 56, 1-20.

Morrison, K. (2008). Educational philosophy and the challenge of complexity theory. In M. Mason (Ed.). Complexity theory and the philosophy of education. Hoboken, NJ: Wiley-Blackwell. 
Noddings, N. (2006). Critical lessons: what our schools should teach. New York: Cambridge University Press.

Osberg, D., Biesta,G., and Cilliers, P. (2008). From representation to emergence: complexity's challenge to the epistemology of schooling. Educational Philosophy and Theory, Vol. 40, No. 1, pp. 213-227

Panikkar, R. (1988). What is comparative philosophy comparing? In P. G. J. Larson \& E. Deutsch, (Eds.). Interpreting Across Religious Boundaries Princeton: Princeton University Press.

Prigogine, I. (1997). The end of certainty. New York: The Free Press.

Parsons, M, (2010), Three versions of creativity in education and art. In D. Araya \& M.A. Peters (Eds.). Education in the creative economy: Knowledge and learning in the age of innovation. New York: Peter Lang, pp. 537-550.

Sagan, C. (1996). The Demon-Haunted World: Science as a Candle in the Dark. New York: Ballantine Books. Saniotis, A. (2007). Mystical mastery: The presentation of Kashf in Sufi divination. Asian Anthropology, 6. Available http://cup.cuhk.edu.hk/ojs/index.php/AsianAnthropology/article/viewArticle/253/516

Serres, M. (1997 [1991]). The troubadour of knowledge. S. Glaser (Trans.). Ann Arbor:University of Michigan Press.

Tyler, R.W. (1949/2009) Basic principles of curriculum and instruction. In D.J. Flinders \& S.J. Thorton (Eds.). The curriculum studies reader (pp. 69-77). New York: Routledge.

UT- Brownsville Collaborative for Excellence in Mathematics and Science Teaching. (2010). Retrieved from http://blue.utb.edu/TRC/About the Collaboratives.html.

\section{About the Author/s}

Laura M. Jewett is an Assistant Professor of Curriculum Theory in the Department of Teaching, Learning and Innovation at The University of Texas at Brownsville. Areas of interest include curriculum, culture, epistemology, and qualitative inquiry. She is the author of A Delicate Dance: Autoethnography, Curriculum and the Semblance of Intimacy and can be contacted at libaiku@hotmail.com.

(C) Copyright 2011. The author, LAURA JEWETT, assigns to the University of Alberta and other educational and non-profit institutions a non-exclusive license to use this document for personal use and in courses of instruction provided that the article is used in full and this copyright statement is reproduced. The author also grants a non-exclusive license to the University of Alberta to publish this document in full on the World Wide Web, and for the document to be published on mirrors on the World Wide Web. Any other usage is prohibited without the express permission of the authors. 